\title{
The Ruffed Grouse
}

M. G. Street, Nipawin

$W^{\mathrm{E}}$ $\mathrm{E}$ had a most welcome and delightful visitor to our feeding and banding station during the wintera female Ruffed Grouse.

Several times, early last fall, a grouse put in an appearance for a brief few moments. However, as soon as winter came in earnest, this grouse (we believe it to be the same one) became a daily visitor.

The chief attraction appeared to be the pulp of chokecherries dropped by a small number of Evening Grosbeaks while feeding at the traps. This it ate in large quantities. Grain was placed in shallow containers, only to be largely ignored. This was quite a surprise to us, and a disappointment too, as chokecherries are not so easily obtained. So feeding this Ruffed Grouse has become somewhat of a problem.

It has also caused us a few anxious moments, as on several occasions we have happened to be watching as it left the park across the street, and came flying swiftly towards our picture-window, swerving at the last moment around the corner of the house to the back where the traps are located. On one occasion it did hit the window with terrific force, but at that, had realized its mistake just in time to check its flight somewhat so that it only lost a few speckled breast feathers, and not its life. It must have got quite a jolt though as it did not appear again that day nor the next, but was present at daylight the following day. The reflection of the trees on the window has also fooled other and smaller birds sometimes-four that we are sure of in three years, with fatal results-three Warblers and a Flycatcher.

When feeding, the Grouse moves cautiously and is ever alert, but is not disturbed greatly by any member of our household, even when closely approached. It will also sit quietly for hours on some low perch, sometimes in a trap. It does carry a U.S. Fish and Wildlife Service band now, and I can truthfully say it was one of the quietest and least alarmed birds I ever banded. Often, after feeding at mid-day, this grouse will bury itself up to its neck in soft snow. This is interesting to seefirst it will squat in the snow and scratch the snow away with its left leg, tilting its body to that side, then scratches with its right, then tilting to that side. This it does alternately until it is completely covered with only an inch or two of neck and head showing. It then is, to anyone not knowing it was there, just a piece of a stick protruding from the snow.

\section{Visitors at Tisdale}

\section{K. E. Baines}

Mountain Bluebirds nest right across this north country, chiefly in telegraph poles. Large flocks of Purple Finches visited here last July during a wet spell. They seemed to feed on green short grass lawns. They were quite tame and came in flocks of several hundred, alternately rising to the trees and returning to the grass. Belted Kingfishers nest in the cut banks of the river adjacent to Tisdale every year. Large flocks of Bohemian Waxwings cleaned up all the Mountain Ash and other berries early in the year. I saw one Red-headed Woodpecker in June, 1950 , and another in June, 1951. Both were near town, both in full plumage and both quite tame. Two Whistling Swans were shot during the hunting season near here last fall. They were mistaken for geese. There were five in the flock. 